\title{
KASUS PTERIGIUM DI POLIKLINIK MATA RSUP PROF. DR. R. D. KANDOU MANADO PERIODE JANUARI - DESEMBER 2011
}

\author{
Margaretha Yumte \\ Laya M. Rares \\ J. S. M. M - Saerang
}

Bagian Ilmu Penyakit Mata Fakultas Kedokteran Universitas Sam Ratulangi Manado

\begin{abstract}
Pterygium is a triangular-shaped tissue growth fibrovascular that grows from the conjunctiva to the cornea in the area interpalpebra. Pterygium of the conjunctiva grows wings shaped in accordance with bulbi.Prevalence pterygium Perdami Clinical Management Guidelines, the incidence is high at Indonesia pterigium equator area 13.1\%.To know pterygium incident at the Ophthalmology Department Prof. Dr. R. D. Kandou Manado period January to December 2011.Retrospective descriptive study by examining the data (card patients) who had examination and treatment in Ophthalmology Department and the medical record Prof. Dr. R. D. Kandou Manado.The research results obtained from the patients of Pterygium is 213 patients were women had the highest number of 122 patients (57.28\%). Pterygium largest number of people in the age group 50-59 years (30.04\%). Largest Occupation the retired of 71 patients (33.33\%). Patient data obtained from recurrent patients as much as 1 patient $(0.52 \%)$. The eyes are the most heavily exposed to the OS pterygium as many as 70 patients $(42.20 \%)$ and the grade of the most much on the grade of patient pterygium II by 67 patients (46.20\%).As much as 213 patients who had examination and treatment with surgery pterygium, pterygium postoperative recurrence in patients with acquired and at least this proves that pterygium postoperative complications are rare these days, although in fact this is complications that are often.Visus good 6/3-6/7,is the most visual acuity found in pterygium with grade of I, II and III, while the grade of IV to normal visual acuity is the most.In IV grade is usually disturbing visual axis and more low visual acuity good vision, is to bad.This is proves that the higher the grade of pterygium the more high influence on our visual function is lowered.
\end{abstract}

Key Word: Pterygium, recurrent data, visual acuity, grade of pterygium

\begin{abstract}
Abstrak: Pterygium adalah pertumbuhan jaringan fibrovaskular berbentuk segitiga yang tumbuh dari arah konjungtiva menuju kornea pada daerah interpalpebra. Pterygium tumbuh berbentuk sayap pada konjungtiva bulbi.Prevalensi pterigium sesuai dengan Panduan Manajemen Klinis Perdami,insidens pterigium cukup tinggi di Indonesia didaerah equator 13,1\%.Penelitian ini untuk mengetahui insiden pterigium di Poliklinik Mata RSUP.Prof.dr.R.D.Kandou periode Januari sampai Desember 2011.Bersifat Deskriptif retrospektif dengan meneliti data rekam medic pasien di poliklinik mata RSUP Prof. Dr. R. D. Kandou Manado.Dari hasil penelitian didapatkan 213 penderita pterigium.Penderita Pterigium berjenis kelamin perempuan memiliki jumlah terbanyak yaitu 122 penderita (57,28\%).Jumlah penderita pterigium terbanyak pada kelompok umur 50-59 tahun(30,04\%).Jenis Pekerjaan terbanyak pada pensiunan yaitu71 penderita(33,33\%).Dari data pasien didapatkan pasien rekuren sebanyak 1 penderita (0,52\%).Bagian mata yang paling banyak terkena pterigium pada OS yaitu sebanyak 70 penderita $(42,20 \%)$ dan derajat yang paling banyak pada penderita pterigium yaitu derajat II sebanyak 67 penderita (46,20\%).Sebanyak 213 penderita yang melakukan pemeriksaan dan menjalani pengobatan maupun operasi pterigium,pterigium postoperasi pada pasien rekuren paling sedikit didapatkan dan hal ini membuktikan bahwa komplikasi pterigium postoperasi akhir ini sudah jarang terjadi walaupun sebenarnya hal ini merupakan komplikasi yang masih sering terjadi.Visus baik/normal 6/3-6/7,5 merupakan visus yang paling banyak ditemukan pada pterigium dengan derajat I,II dan III sedangkan pada derajat IV untuk visus normal ini adalah
\end{abstract}


yang paling sedikit.Pada derajat IV ini biasanya sudah mengganggu aksis visual dan lebih banyak visus low vision baik,sedang sampai buruk.Hal ini membuktikan bahwa semakin tinggi derajat pterigium maka semakin tinggi pengaruhnya pada fungsi visual kita menjadi menurun.

Kata Kunci: Pterigium,data rekuren,visus, derajat pterigium

\section{TUJUAN DAN MANFAAT}

Tujuan: Untuk mengetahui insiden pterigium di Poliklinik Mata RSUP Prof. Dr. R. D. Kandou periode Januari sampai Desember 2011.

Manfaat: Dapat mengetahui insiden pterigium di Poliklinik Mata RSUP Prof. Dr. R. D. Kandou periode Januari sampai Desember 2011

\section{METODOLOGI PENELITIAN}

Penelitian ini bersifat deskriptif retrospektif dengan melihat status pasien dan data rekam medic pasien Pterigium.Penelitian ini dilakukan 1 Januari sampai 31 Desember 2011.Penelitian ini di lakukan di Bagian Mata di BLU RSUP Prof. Dr. R. D. Kandou Manado.Subyek penelitian adalah semua pasien yang di diagnose pterigium yang melakukan pemeriksaan dan pengobatan di Bagian Mata RSUP Prof. Dr. R. D. Kandou periode 2011.

\section{HASIL PENELITIAN}

Tabel 1. Distribusi Pasien Pterigium Berdasarkan Jenis Kelamin

\begin{tabular}{lll}
\hline Jenis Kelamin & Jumlah kasus (pasien) & Persentase (\%) \\
\hline Laki-laki & 91 & 42.72 \\
Perempuan & 122 & 57.28 \\
Total & $\mathbf{2 1 3}$ & $\mathbf{1 0 0}$ \\
\hline
\end{tabular}

Tabel 2. Distribusi Pasien Pterigium Berdasarkan Kelompok Umur

\begin{tabular}{lll}
\hline Umur & Jumlah kasus (pasien) & Persentase (\%) \\
\hline$\leq \mathbf{2 9}$ & 3 & 1.41 \\
$\mathbf{3 0 - 3 9}$ & 20 & 9.4 \\
$\mathbf{4 0 - 4 9}$ & 39 & 18.31 \\
$\mathbf{5 0}-\mathbf{5 9}$ & 64 & 30.04 \\
$\mathbf{6 0}-\mathbf{6 9}$ & 58 & 27.23 \\
$\mathbf{2 7 0}$ & 29 & 13.61 \\
Total & $\mathbf{2 1 3}$ & $\mathbf{1 0 0}$ \\
\hline
\end{tabular}


Tabel 3. Distribusi Pasien Pterigium Berdasarkan Pekerjaan

\begin{tabular}{lll}
\hline Jenis Pekerjaan & Jumlah kasus (pasien) & Persentase (\%) \\
\hline Petani & 9 & 4.22 \\
Pegawai & 52 & 24.41 \\
\hline Swasta & 28 & 13.14 \\
Ibu Rumah Tangga & 33 & 15.49 \\
Pensiunan & 71 & 33.33 \\
Tidak ada pekerjaan & 20 & 9.40 \\
Total & $\mathbf{2 1 3}$ & $\mathbf{1 0 0}$ \\
\hline
\end{tabular}

Tabel 4. Distribusi Pasien Pterigium Berdasarkan Data Pasien

\begin{tabular}{lll}
\hline Data kasus & Jumlah kasus (pasien) & Persentase (\%) \\
\hline Pasien baru & 190 & 99.48 \\
\hline Pasien rekuren & 1 & 0.52 \\
Total & $\mathbf{1 9 1}$ & $\mathbf{1 0 0}$ \\
\hline
\end{tabular}

Tabel 5. Distribusi Pasien Pterigium Berdasarkan Mata Yang Terkena Pterigium

\begin{tabular}{lll}
\hline Visus & Jumlah kasus (pasien) & Persentase (\%) \\
\hline OD & 50 & 30.12 \\
OS & 70 & 42.20 \\
ODS & 46 & 27.72 \\
Total & $\mathbf{1 6 6}$ & $\mathbf{1 0 0}$ \\
\hline
\end{tabular}

Tabel 6. Distribusi Pasien Pterigium Berdasarkan Klasifikasi Pterigium Dengan Visus

\begin{tabular}{|c|c|c|c|c|c|c|c|c|c|}
\hline \multirow[t]{3}{*}{ NO } & \multirow[t]{3}{*}{ Visus } & \multicolumn{8}{|c|}{ Jumlah Kasus (Pasien) } \\
\hline & & \multicolumn{2}{|c|}{ Derajat I } & \multicolumn{2}{|c|}{ Derajat II } & \multicolumn{2}{|c|}{ Derajat III } & \multicolumn{2}{|c|}{ Derajat IV } \\
\hline & & VOD & VOS & VOD & VOS & VOD & VOS & VOD & VOS \\
\hline 1 & $\leq 6 / 7.5$ & 20 & 16 & 29 & 26 & 11 & 10 & 3 & 1 \\
\hline 2 & $6 / 8.5-6 / 21$ & 8 & 12 & 24 & 32 & 12 & 18 & 1 & \\
\hline 3 & $6 / 24-6 / 30$ & 1 & 2 & 8 & 2 & 6 & & 1 & 2 \\
\hline 4 & $\geq 6 / 60$ & 1 & & 6 & 7 & 7 & 8 & 7 & 9 \\
\hline \multirow{2}{*}{\multicolumn{2}{|c|}{$\begin{array}{l}\text { Total / } \\
\text { Persentase }\end{array}$}} & \multicolumn{2}{|c|}{$30 / 20.70 \%$} & \multicolumn{2}{|c|}{67 | $46.20 \%$} & \multicolumn{2}{|c|}{$36 / 24.82 \%$} & \multicolumn{2}{|c|}{$12 / 8.28 \%$} \\
\hline & & \multicolumn{4}{|c|}{$145 / 100 \%$} & & & & \\
\hline
\end{tabular}

\section{BAHASAN}

Penelitian yang dilakukan melalui data rekam medic di Poliklinik Mata periode 2011,tercatat 213 pasien yang di rawat dengan diagnosis pterigium.Data tersebut insiden tertinggi perempuan 122 pasien,kelompok umur 50-59 tahun 64 pasien, pekerjaan pensiunan 71 pasien, data pasien rekuren 1 pasien,bagian mata yang terkena pterigium visus OS 70 pasien, klasifikasi dengan visus VOD VOS Derajat 
II 67 pasien.Hal ini menunjukkan bahwa kasus pterigium hingga saat ini di Indonesia masih merupakan insiden yang cukup tinggi terutama di daerah equator $13,1 \%$ dan berhubungan dengan factor umur, jenis kelamin, pendidikan rendah, riwayat terpapar lingkungan di luar rumah, factor genetic maupun factor lain seperti iritasi kronik atau inflamasi.

\section{SIMPULAN}

Berdasarkan hasil penelitian yang di lakukan secara retrospektif mengenai insiden Pterigium berdasarkan Jenis Kelamin, kelompok umur, pekerjaan, data pasien, bagian mata yang terkena dan klasifikasi dengan visus di BLU RSUP Prof. R. D. Kandou Manado,maka dapat di tarik kesimpulan :

1. Perempuan memiliki insiden lebih tinggi dari laki-laki

2. Kelompok umur 50-59 tahun memiliki insiden yang lebih tinggi dari kelompok umur lainnya

3. Pekerjaan pensiunan memiliki insiden yang tinggi dari jenis pekerjaan lainnya

4. Pasien baru memiliki insiden yang lebih tinggi
5. Visus OS memiliki insiden yang tinggi daripada visus OD

6. Visus OD OS Derajat II memiliki insiden yang tinggi

\section{DAFTAR PUSTAKA}

1. Ilyasi S. Pterigium,dalam ilmu penyakit mata.Jakarta:Penerbit Fakultas Kedokteran Universitas Indonesia;2010

2. Ilyasi S,dkk. Ilmu Penyakit Mata.Jakarta:Penerbit CV.Sagung Seto;2010

3. Gazzard G, Saw S-M, Farook M, Koh D, Widjadja D, Chia S-E, Hong C- Y, and Tan D-T. Pterygium in indonesia : Prevelance, severity, and risk factors. Br J Ophtalmogy 2002; 86: 1341-46. Diunduh dari URL: http://bjo.bjm.com/cgi/reprint/86/12/1341.p df diakses 9 November, 2011.

4. Pterigium Universitas Sumatera Utara Chapter I. Diunduh dari: http:// isjd.pdii.lipi.go.id/admin /jurnal/ 421192657662.pdf

5. Ilyasi S, dkk. Ilmu Penyakit Mata: Untuk Dokter dan Mahasiswa Kedokteran. Edisi ke-2 Jakarta: Penerbit CV. Sagung Seto; 2010. H. 297-98.

6. Depkes R. I. rencana strategi nasional: penanggulangan gangguan penglihatan dan kebutaan ( PGPK ) untuk mencapai vision 2020. Jakarta; 2003. h. 1.12 